NOTICE: This is the author's version of a work that was accepted for publication in Applied Catalysis B: Environmental. Changes resulting from the publishing process, such as peer review, editing, corrections, structural formatting and other quality control mechanisms may not be reflected in this document. Changes may have been made to this work since it was submitted for publication. A definitive version was subsequently published in Applied Catalysis B: Environmental, Volumes 142-143, October-November 2013, Pages 729-735. http://doi.org/10.1016/j.apcatb.2013.06.004 


\title{
Manganese oxides at different oxidation states for heterogeneous activation of peroxymonosulfate for phenol degradation in aqueous solutions
}

\author{
Edy Saputra ${ }^{1,2}$, Syaifullah Muhammad ${ }^{1,3}$, Hongqi Sun ${ }^{1}$, Ha-Ming Ang ${ }^{1}$, Moses O. Tadé ${ }^{1}$, Shaobin \\ Wang $^{1, *}$ \\ ${ }^{1}$ Department of Chemical Engineering and CRC for Contamination Assessment and Remediation of \\ the Environment (CRC-CARE), Curtin University, GPO Box U1987, Perth, WA 6845, Australia \\ ${ }^{2}$ Department of Chemical Engineering, Riau University, Pekanbaru 28293, Indonesia \\ ${ }^{3}$ Department of Chemical Engineering, Syiah Kuala University, Banda Aceh, Indonesia
}

\begin{abstract}
A series of manganese oxides $\left(\mathrm{MnO}, \mathrm{MnO}_{2}, \mathrm{Mn}_{2} \mathrm{O}_{3}\right.$ and $\left.\mathrm{Mn}_{3} \mathrm{O}_{4}\right)$ were synthesized and tested in heterogeneous activation of peroxymonosulfate (PMS) for phenol degradation in aqueous solutions. Their properties were characterized by several techniques such as X-ray diffraction (XRD), thermogravimetric analysis (TGA), scanning electron microscopy (SEM), and $\mathrm{N}_{2}$ adsorption/desorption isotherms. Catalytic activities of Mn oxides were found to be closely related to the chemical states of $\mathrm{Mn}$. $\mathrm{Mn}_{2} \mathrm{O}_{3}$ is highly effective in heterogeneous activation of PMS to produce sulfate radicals for phenol degradation compared with other catalysts $\left(\mathrm{MnO}, \mathrm{MnO}_{2}\right.$, and $\mathrm{Mn}_{3} \mathrm{O}_{4}$ ). The activity shows an order of $\mathrm{Mn}_{2} \mathrm{O}_{3}>\mathrm{MnO}>\mathrm{Mn}_{3} \mathrm{O}_{4}>\mathrm{MnO}_{2} . \mathrm{Mn}_{2} \mathrm{O}_{3}$ could completely remove phenol in $60 \mathrm{~min}$ at the conditions of $25 \mathrm{ppm}$ phenol, $0.4 \mathrm{~g} / \mathrm{L}$ catalyst, $2 \mathrm{~g} / \mathrm{L}$ PMS, and 25 ${ }^{\circ} \mathrm{C}$. After heat regeneration, the activity could be fully recovered. A pseudo first order model would fit to phenol degradation kinetics and activation energy was obtained as $11.4 \mathrm{~kJ} / \mathrm{mol}$.
\end{abstract}

Key words: Mn oxides, peroxymonosulfate activation, advanced oxidation, phenol degradation

*Correspondence author. Email: Shaobin.wang@curtin.edu.au 


\section{Introduction}

Over the last decades, water treatment plays an important role in our lives, because of fresh water crisis and the increasing awareness of human health and ecological systems as a result of industrial waste pollution. Industrial activities generate large amounts of organic hazardous substances discharged into the environment. The organic wastes can be found in many industries as byproducts such as petroleum refining, petrochemical, pharmaceutical, plastic, pesticides, chemical industries, agrochemicals, and pulp and paper industries $[1,2]$. The organic pollutants e.g. phenol, are toxic and cause considerable damage and threat to the ecosystem in water bodies and to the human health even at low concentrations[3]. It is important to dispose of wastewater in a proper way in order to comply with environmental regulations. However, the organics in wastewaters from chemical and related industries cannot be well treated by conventional processes due to degradation of these pollutants being very slow or ineffective and not environmentally compatible $[4,5]$. The most promising method for degradation of organic pollutants in wastewater is advanced oxidation processes (AOPs). AOPs are based on generation and utilization of reactive species, such as hydroxyl radicals $(\mathrm{HO} \bullet)$ that have a high standard oxidation potential and react none selectively [6, 7]. Heterogeneous catalytic oxidation systems have recently attracted much interest due to easily recovery and reuse of the catalysts [8].

Lately, manganese oxides, such as $\mathrm{MnO}, \mathrm{MnO}_{2}, \mathrm{Mn}_{2} \mathrm{O}_{3}$ and $\mathrm{Mn}_{3} \mathrm{O}_{4}$, have attracted much attention due to their physical and chemical properties for being used as catalysts, adsorbents, supercapacitors, and battery materials [9-15]. Kim and Shim [16] have conducted a study on the catalytic combustion of aromatic hydrocarbons (benzene and toluene) on manganese oxides. The results indicated that the catalysts showed high activity in the oxidation of hydrocarbons at temperatures below $300{ }^{\circ} \mathrm{C}$. Furthermore, the reactivity of catalysts exhibited an order of $\mathrm{Mn}_{3} \mathrm{O}_{4}>$ $\mathrm{Mn}_{2} \mathrm{O}_{3}>\mathrm{MnO}_{2}$, which was correlated with oxygen mobility on the catalysts. Ramesh et al. [17] have studied $\mathrm{CO}$ oxidation over a series of manganese oxide catalysts and found that $\mathrm{Mn}_{2} \mathrm{O}_{3}$ is the best catalyst, with the sequence of catalytic activity as $\mathrm{MnO} \leq \mathrm{MnO}_{2}<\mathrm{Mn}_{2} \mathrm{O}_{3}$. Santos et al. [18] reported the synthesis of manganese oxide nanoparticles for ethyl acetate oxidation. Complete oxidation of ethyl acetate was achieved at temperature below $300{ }^{\circ} \mathrm{C}$. However, few investigations have been conducted in the activity of a series of manganese oxides at different valence states in water treatment.

In the most of previous investigations in water treatment, $\mathrm{MnO}_{\mathrm{x}}$ was usually used for Fenton-like reaction for production of hydroxyl radicals from $\mathrm{H}_{2} \mathrm{O}_{2}$ and oxidation of organic compounds. Recently, sulfate radicals (SRs) produced by $\mathrm{Co}^{2+} / \mathrm{oxone}$ (peroxymonosulfate, PMS) or $\mathrm{Ru}^{3+} /$ oxone 
have attracted intense attention in degradation of organic compounds for water treatment [19, 20]. However, $\mathrm{Co}^{2+}$ or $\mathrm{Ru}^{3+}$ may generate secondary pollution [21-23]. Therefore, alternative metal such as $\mathrm{Fe}^{2+}$, has been proposed by Zazo et al. [24]. They found that $\mathrm{Fe}^{2+} / \mathrm{H}_{2} \mathrm{O}_{2}$ have a high catalytic activity for degradation of phenol. In contrary, a recent study by Watts et al. [25] revealed that $\mathrm{Mn}^{2+} / \mathrm{H}_{2} \mathrm{O}_{2}$ was significantly more reactive than $\mathrm{Fe}^{2+} / \mathrm{H}_{2} \mathrm{O}_{2}$. Moreover, they found that catalytic activity was influenced significantly by pH. Saputra et al. [26] reported the oxidative removal of phenol from water by $\mathrm{MnO}_{2}$ and studied the factors influencing the reactions. They found that $\mathrm{MnO}_{2}$ exhibited as a promising chemical agent under certain conditions for phenol removal from wastewater. However, no further investigation has been reported for solid $\mathrm{MnO}_{\mathrm{x}}$ for the activation of PMS to generate SRs.

In this research, we investigate the performance of a series of manganese oxides at varying valence states for heterogeneous generation of SRs for chemical mineralization of phenol in the solution. These catalysts will be an alternative for heterogeneous AOP. Several key parameters in the kinetic study such as phenol concentration, catalyst loading, PMS concentration and temperature were investigated. Regeneration of used catalysts was also investigated.

\section{Experimental methods}

\subsection{Preparation of Mn catalysts}

A manganese dioxide $\left(\mathrm{MnO}_{2}\right)$ was purchased from Sigma-Aldrich Company and used without further treatment. $\mathrm{Mn}_{2} \mathrm{O}_{3}$ was obtained by treating the $\mathrm{MnO}_{2}$ at $550{ }^{\circ} \mathrm{C}$ in air for $5 \mathrm{~h}$. In addition, $\mathrm{MnO}_{2}$ was calcined at $950{ }^{\circ} \mathrm{C}$ in air for $2 \mathrm{~h}$ to get $\mathrm{Mn}_{3} \mathrm{O}_{4}$. Another catalyst $(\mathrm{MnO})$ was obtained by a two-step method. First, $\mathrm{MnCO}_{3}$ was synthesized by a hydrothermal method [27] and then calcination was made. Typically, $\mathrm{KMnO}_{4}(3 \mathrm{mmol})$ and an equal amount of glucose were put into distilled water at room temperature to form a homogeneous solution, which was transferred into a $45 \mathrm{~mL}$ Teflon-lined autoclave. The autoclave was sealed and maintained at $150{ }^{\circ} \mathrm{C}$ for $10 \mathrm{~h}$, and was then cooled down to room temperature naturally. The resulted solid product $\left(\mathrm{MnCO}_{3}\right)$ was filtered, washed with distilled water and dried in air at $100{ }^{\circ} \mathrm{C}$ overnight. Finally, $\mathrm{MnO}$ catalyst was obtained by calcination of $\mathrm{MnCO}_{3}$ at $500{ }^{\circ} \mathrm{C}$ under argon flow at the rate $60 \mathrm{~mL} / \mathrm{min}$ for $2 \mathrm{~h}$.

\subsection{Characterization of catalysts}

Catalysts were characterized by X-ray diffraction (XRD), $\mathrm{N}_{2}$ adsorption/desorption isotherm, scanning electron microscopy (SEM) and thermogravimetric analysis (TGA). XRD patterns were obtained on a Bruker D8 (Bruker-AXS, Karlsruhe, Germany) diffractometer using filtered $\mathrm{Cu} \mathrm{Ka}$ 
radiation source $(\lambda=1.54178 \AA)$, with accelerating voltage $40 \mathrm{kV}$, current $30 \mathrm{~mA}$ and scanned at $2 \theta$ from 5 to $70^{\circ} . \mathrm{N}_{2}$ adsorption/desorption was measured using a Micromeritics Tristar 3000 to obtain pore volume and the Brunauer-Emmett-Teller (BET) specific surface area. Prior to measurement the samples were degased at $120{ }^{\circ} \mathrm{C}$ for $5 \mathrm{~h}$ under vacuum condition. The external morphology and chemical compositions of the samples were observed on a ZEISS NEON 40EsB scanning electron microscope (SEM) equipped with an energy dispersive spectrometer (SEM-EDS).

\subsection{Kinetic study of phenol oxidation}

The catalytic oxidation of phenol was carried out in a $1 \mathrm{~L}$ glass beaker containing 25-100 ppm of phenol solutions $(500 \mathrm{~mL})$, which was attached to a stand and dipped in a water bath with a temperature controller. The reaction mixture was stirred constantly at $400 \mathrm{rpm}$ to maintain a homogenous solution. A fixed amount of peroxymonosulfate (using Oxone, Dupont's triple salt, $2 \mathrm{KHSO}_{5} \bullet \mathrm{KHSO}_{4} \bullet \mathrm{K}_{2} \mathrm{SO}_{4}$ (PMS), Sigma-Aldrich) was added into the solution and allowed to dissolve completely before reaction. Further, a fixed amount of catalyst was added into the reactor to start the oxidation reaction of phenol. The reaction was carried on for $120 \mathrm{~min}$ and at a fixed time interval, $0.5 \mathrm{~mL}$ of solution sample was taken from the mixture using a syringe with a filter of 0.45 $\mu \mathrm{m}$ and then mixed with $0.5 \mathrm{~mL}$ methanol to quench the reaction. Concentration of phenol was analyzed using a HPLC with a UV detector at wavelength of $270 \mathrm{~nm}$. The column used was C-18 with a mobile phase of $30 \%$ acetonitrile and $70 \%$ ultrapure water. For selected samples, total organic carbon (TOC) was obtained using a Shimadzu TOC-5000 CE analyzer. For the measurement of TOC, $5 \mathrm{~mL}$ solutions were extracted at a fixed interval and quenched with $5 \mathrm{~mL}$ of $3 \mathrm{M}$ sodium nitrite solution and then analyzed on the TOC analyzer.

For recycled catalyst tests, two regeneration methods were used. One is simple washing treatment and the other is high-temperature calcination. In general, Mn oxides were collected by filtration after reaction, washing with water and drying at $80{ }^{\circ} \mathrm{C}$ overnight for reuse test. Some dried samples were further calcined at $500{ }^{\circ} \mathrm{C}$ in air for $1 \mathrm{~h}$ and then reused for test again.

\section{Result and discussion}

\subsection{Characterization of manganese oxide catalysts}

$\mathrm{MnO}_{2}$ and $\mathrm{MnCO}_{3}$ were studied by TGA under air and argon atmosphere, respectively (Fig. 1). The TGA pattern of $\mathrm{MnO}_{2}$ (Fig. 1A) shows $5 \%$ weight loss below $300{ }^{\circ} \mathrm{C}$, which corresponds to a loss of surface adsorbed water, organic and trace amount of oxygen. At around $550{ }^{\circ} \mathrm{C}$, weight loss of about $8 \%$ corresponds to the loss of oxygen from $\mathrm{MnO}_{2}$ lattice resulting in the phase transformation 
to $\mathrm{Mn}_{2} \mathrm{O}_{3}$. Another $5 \%$ weight loss at around $950{ }^{\circ} \mathrm{C}$ corresponds to continuous loss of oxygen resulting in further phase transformation from $\mathrm{Mn}_{2} \mathrm{O}_{3}$ to $\mathrm{Mn}_{3} \mathrm{O}_{4}$. For $\mathrm{MnCO}_{3}$, TGA pattern in Fig.1B shows $10 \%$ weight loss below $350{ }^{\circ} \mathrm{C}$, which corresponds to a loss of water, organic and trace amount of carbon dioxide, and another $29 \%$ weight loss at around $450{ }^{\circ} \mathrm{C}$ corresponds to loss of carbon dioxide from $\mathrm{MnCO}_{3}$ lattice resulting in the phase transformation to $\mathrm{MnO}$. The nature of TGA and different phase transitions are agreement with the previous reports for $\mathrm{MnO}_{2}$ and $\mathrm{MnCO}_{3}$ $[28,29]$.

\section{[Insert Fig. 1]}

Fig. 2 shows XRD patterns of four manganese oxides. The four samples present different crystalline peaks. In Fig. 2A, the diffraction peaks occurred at $22.43^{\circ}, 34.46^{\circ}, 37.12^{\circ}, 38.78^{\circ}$, and $57.36^{\circ}$, corresponding to the diffractions of $\gamma-\mathrm{MnO}_{2}$ (JCPDS No. 14-0664, $a=6.360 \AA$ ). The diffraction peaks in Fig. 2B occurred at $34.94^{\circ}, 40.57^{\circ}, 58.72^{\circ}, 70.19^{\circ}$, and $73.81^{\circ}$, confirming the structure of $\mathrm{MnO}$ (JCPDS No. 75-0626, $a=4.444 \AA$ ). In Fig. 2C, the diffraction peaks occurred at $28.91^{\circ}$, $30.99^{\circ}, 32.38^{\circ}, 36.08^{\circ}, 38.09^{\circ}, 44.40^{\circ}, 50.83^{\circ}, 53.86^{\circ}$ and $59.90^{\circ}$, corresponding to $\gamma-\mathrm{Mn}_{3} \mathrm{O}_{4}(\mathrm{JCPDS}$ No. 80-0382, $a=5.749 \AA$ ) while in Fig. 2D the diffraction peaks occurred at $23.08^{\circ}, 32.84^{\circ}, 38.14^{\circ}$, $45.05^{\circ}, 49.22^{\circ}, 55.04^{\circ}$, and $65.16^{\circ}$, confirming the crystalline structure of $\alpha-\mathrm{Mn}_{2} \mathrm{O}_{3}$ (JCPDS No. 894836, $a=9.406 \AA$ ). Those XRD results show the successful synthesis of $\mathrm{MnO}, \mathrm{Mn}_{2} \mathrm{O}_{3}$ and $\mathrm{Mn}_{3} \mathrm{O}_{4}$ compounds from thermal decomposition of $\mathrm{MnCO}_{3}$ and $\mathrm{MnO}_{2}$.

\section{[Insert Fig. 2]}

SEM images show that $\mathrm{MnO}_{2}, \mathrm{Mn}_{2} \mathrm{O}_{3}$ and $\mathrm{Mn}_{3} \mathrm{O}_{4}$ present as spherical particles with a small particle size of $50 \mathrm{~nm}$ while $\mathrm{MnO}$ presents in cubic form with a large particle size of $1 \mu \mathrm{m}$.

Fig. 3 shows $\mathrm{N}_{2}$ adsorption/desorption isotherms and pore size distributions of manganese oxides. The BET surface area, pore volume and average pore size are given in Table $1 . \mathrm{Mn}_{3} \mathrm{O}_{4}$ has higher surface area $\left(157 \mathrm{~m}^{2} \mathrm{~g}^{-1}\right)$ than others while $\mathrm{Mn}_{2} \mathrm{O}_{3}$ has higher pore volume and pore radius. $\mathrm{MnO}$ shows the lowest surface area, pore volume and pore radius. Furthermore, all catalysts have pore radius between $20 \AA$ and $80 \AA$, which means they are mesoporous materials. The pore size distribution profiles show that $\mathrm{MnO}, \mathrm{Mn}_{3} \mathrm{O}_{4}$, and $\mathrm{MnO}_{2}$ present a single mode of pore size, which is centred at 37.2, 26.3, and 29.1 $\AA$, respectively. $\mathrm{Mn}_{2} \mathrm{O}_{3}$ shows two modes, centred at 18.2 and $32.7 \AA$, respectively, indicating that $\mathrm{Mn}_{2} \mathrm{O}_{3}$ is a typical micro and mesoporous material.

\section{[Insert Fig. 3]}


Table 1. Surface area, pore volume and pore radius of a series of manganese oxides.

\begin{tabular}{llllll}
\hline Catalyst & Structure & Coordination & $\begin{array}{l}\text { Surface area } \\
\left(\mathrm{S}_{\mathrm{BET}}, \mathrm{m}^{2} \cdot \mathrm{g}^{-1}\right)\end{array}$ & $\begin{array}{l}\text { Pore volume } \\
\left(\mathrm{cm}^{3} \cdot \mathrm{g}^{-1}\right)\end{array}$ & $\begin{array}{l}\text { Average pore radius } \\
(\AA)\end{array}$ \\
\hline $\mathrm{Mn}_{3} \mathrm{O}_{4}$ & Spinel & 4,6 & 157.0 & 0.237 & 30.1 \\
$\mathrm{Mn}_{2} \mathrm{O}_{3}$ & "C" bixbyite & $6($ Octahedral $)$ & 95.4 & 0.336 & 70.4 \\
$\mathrm{MnO}_{2}$ & Rutile & $6($ Octahedral $)$ & 104.1 & 0.191 & 36.6 \\
$\mathrm{MnO}$ & Rock salt & $6($ Octahedral $)$ & 57.7 & 0.169 & 22.5 \\
\hline
\end{tabular}

\subsection{Preliminary study of phenol oxidation on Mn-oxide catalysts}

Fig.4 shows phenol degradation efficiency on a series of Mn oxides at varying oxidation states. Adsorption tests showed that Mn oxides presented minor adsorption of phenol, giving less than $10 \%$ in 120 min, which is due to low surface area[26]. In catalytic oxidation tests, addition of PMS without the presence of a catalyst did not induce phenol oxidation reaction. Phenol degradation would only occur when Mn oxide catalyst and oxidant (PMS) were simultaneously present in the solution. In a comparison of all catalyst performances, $\mathrm{Mn}_{2} \mathrm{O}_{3}$ is most effective in activating PMS to generate sulfate radicals. $\mathrm{Mn}_{2} \mathrm{O}_{3}$-PMS exhibited much better performance, producing complete removal of phenol in $60 \mathrm{~min}$ while the other three showed low phenol degradation. The results also showed that about $90 \%, 66.4 \%$, and $61.5 \%$ of phenol removal were obtained for MnO-PMS, $\mathrm{Mn}_{3} \mathrm{O}_{4}$-PMS and $\mathrm{MnO}_{2}$-PMS, respectively, within $120 \mathrm{~min}$. Thus, the order of the catalytic activity of the series of catalysts is as follows: $\mathrm{Mn}_{2} \mathrm{O}_{3}>\mathrm{MnO}>\mathrm{Mn}_{3} \mathrm{O}_{4}>\mathrm{MnO}_{2}$, according to the conversion profiles. This reveals that the catalytic activity is apparently dependent on the oxidation state of manganese. In addition, TOC removal in $\mathrm{Mn}_{2} \mathrm{O}_{3}$-PMS system was also examined and about $86.39 \%$ of TOC removal was obtained within $120 \mathrm{~min}$.

Previously, $\mathrm{Mn}^{2+}$ has been investigated for the activation of ozone or $\mathrm{H}_{2} \mathrm{O}_{2}$ to produce hydroxyl radicals for several organics oxidation and it showed effective activity. Lie at al. [30] investigated homogeneous activation of ozone with $\mathrm{Mn}^{2+}$ for 2-chloro-2',6'-diethyl-N-methoxymethyl acetanilide oxidation and found that $\mathrm{Mn}^{2+}$ is an effective metal ion for the activation of ozone. Anipsitakis and Dionysiou [20] studied $\mathrm{Mn}^{2+}$ for activation of $\mathrm{H}_{2} \mathrm{O}_{2}$ and PMS to found that $\mathrm{Mn}^{2+}$ could activate $\mathrm{H}_{2} \mathrm{O}_{2}$ and PMS to produce hydroxyl radicals and SRs, respectively, although the rate of reaction was still low. 
Several heterogeneous cobalt systems have also been tested in activation of peroxymonosulfate for oxidation of toxic organics in water. Shukla et al. used $\mathrm{Co}_{3} \mathrm{O}_{4}-\mathrm{SiO}_{2}$ [31] and Co-SBA-15 [32] with peroxymonosulfate for phenol degradation at $30 \mathrm{ppm} . \mathrm{Co}_{3} \mathrm{O}_{4}-\mathrm{SiO}_{2}$ could achieve complete degradation of phenol in 190 min while Co-SBA-15 could achieve 100\% phenol degradation within 180 min. Yang et al. [33] used $\mathrm{Co}-\mathrm{Fe}$ mixed oxide $\left(\mathrm{CoFeO}_{4}\right)$ nanocatalyst for heterogeneous activation of peroxymonosulfate to generate SRs targeting the decomposition of 2,4-dichlorophenol (2,4-DCP). Co-Fe oxide could achieve 80\% 2,4-DCP degradation in $120 \mathrm{~min}$. Anipsitakis and Dionysiou [20] studied homogeneous activation of peroxymonosulfate with $\mathrm{Mn}^{2+}$ for 2,4-DCP oxidation. It was reported that $24 \%$ of $2,4-\mathrm{DCP}$ removal could be achieved at 2,4-DCP concentration of $50 \mathrm{ppm}$ in $240 \mathrm{~min}$ of reaction time. Therefore, it is seen that $\mathrm{Mn}_{2} \mathrm{O}_{3}$ presented a higher activity in phenol degradation than $\mathrm{Mn}^{2+}$ and most of reported heterogeneous Co systems.

\section{[Insert Fig. 4]}

In this investigation, $\mathrm{Mn}$ oxides at different oxidation states can activate peroxymonosulfate to produce $\mathrm{SRs}\left(\mathrm{SO}_{4}^{-\bullet}\right.$ and $\left.\mathrm{SO}_{5}^{-{ }^{-}}\right)$for phenol degradation as shown in the following equations.

$$
\begin{aligned}
& \mathrm{HSO}_{5}^{-}+2 \mathrm{MnO}_{2} \rightarrow \mathrm{Mn}_{2} \mathrm{O}_{3}+\mathrm{SO}_{5}^{-\bullet}+\mathrm{OH}^{-} \\
& \mathrm{HSO}_{5}{ }^{-}+2 \mathrm{Mn}_{3} \mathrm{O}_{4} \rightarrow 3 \mathrm{Mn}_{2} \mathrm{O}_{3}+\mathrm{SO}_{4}^{-\bullet}+\mathrm{H}^{+} \\
& \mathrm{HSO}_{5}^{-}+\mathrm{Mn}_{2} \mathrm{O}_{3} \rightarrow 2 \mathrm{MnO}_{2}+\mathrm{SO}_{4}^{-\bullet}+\mathrm{H}^{+} \\
& \mathrm{HSO}_{5}^{-}+2 \mathrm{MnO} \rightarrow \mathrm{Mn}_{2} \mathrm{O}_{3}+\mathrm{SO}_{4}^{-\bullet}+\mathrm{H}^{+} \\
& \mathrm{HSO}_{5}^{-}+3 \mathrm{Mn}_{2} \mathrm{O}_{3} \rightarrow 2 \mathrm{Mn}_{3} \mathrm{O}_{4}+\mathrm{SO}_{5}^{-\bullet}+\mathrm{OH}^{-} \\
& \mathrm{SO}_{4}^{-\bullet}+\mathrm{H}_{2} \mathrm{O} \rightarrow \mathrm{OH}^{\bullet}+\mathrm{H}^{+}+\mathrm{SO}_{4}{ }^{2-} \\
& \mathrm{C}_{6} \mathrm{H}_{5} \mathrm{OH}+\mathrm{SO}_{4}^{-} \rightarrow \text { several steps } \rightarrow \mathrm{CO}_{2}+\mathrm{H}_{2} \mathrm{O}+\mathrm{SO}_{4}{ }^{2-} \\
& \mathrm{C}_{6} \mathrm{H}_{5} \mathrm{OH}+\mathrm{SO}_{5}^{-\bullet} \rightarrow \text { several steps } \rightarrow \mathrm{CO}_{2}+\mathrm{H}_{2} \mathrm{O}+\mathrm{SO}_{4}{ }^{2-}
\end{aligned}
$$

The reactivity of $\mathrm{MnO}, \mathrm{Mn}_{2} \mathrm{O}_{3}, \mathrm{Mn}_{3} \mathrm{O}_{4}$ and $\mathrm{MnO}_{4}$ is likely associated with the capacity of manganese to form various oxidation states, e.g., redox reaction of $\mathrm{Mn}^{2+} / \mathrm{Mn}^{3+}$ or $\mathrm{Mn}^{3+} / \mathrm{Mn}^{4+}$, and "oxygen mobility", in the oxide lattice. In general, $\mathrm{Mn}^{3+}$ tends to undergo disproportionation reaction under the influence of $\mathrm{H}^{+}$and $\mathrm{OH}^{-}$, thus, $\mathrm{Mn}_{2} \mathrm{O}_{3}$ can activate PMS via reactions (3) and (5) to produce $\mathrm{SO}_{4}^{-\bullet}$ and $\mathrm{SO}_{5}^{-\bullet}$, respectively. $\mathrm{MnO}_{2}$ and $\mathrm{MnO}$, however, will activate $\mathrm{PMS}$ via reactions (1) or (4) to generate $\mathrm{SO}_{5}^{-\bullet}$ and $\mathrm{SO}_{4}^{-\bullet}$, respectively. Due to the higher activity of $\mathrm{SO}_{4}^{-\bullet}$ than $\mathrm{SO}_{5}^{-\bullet}$, $\mathrm{MnO}$ presents a higher phenol degradation rate. $\mathrm{Mn}_{3} \mathrm{O}_{4}$ will produce $\mathrm{SO}_{4}{ }^{-\bullet}$ via reaction (2). But due 
to lower redox potential, $\mathrm{Mn}_{3} \mathrm{O}_{4}$ is less active than $\mathrm{MnO}$. Therefore, the activities of $\mathrm{MnO}, \mathrm{Mn}_{2} \mathrm{O}_{3}$, $\mathrm{Mn}_{3} \mathrm{O}_{4}$ and $\mathrm{MnO}_{4}$ present in the order of $\mathrm{Mn}_{2} \mathrm{O}_{3}>\mathrm{MnO}>\mathrm{Mn}_{3} \mathrm{O}_{4}>\mathrm{MnO}_{2}$.

\subsection{Effects of reaction parameters on phenol degradation on $\mathrm{Mn}_{2} \mathrm{O}_{3}$}

Due to high activity of $\mathrm{Mn}_{2} \mathrm{O}_{3}$, further investigations on $\mathrm{Mn}_{2} \mathrm{O}_{3}$ were carried out to understand the effects of operating conditions. The effect of initial phenol concentration at 25, 50, 75 and 100 $\mathrm{mg} / \mathrm{L}$ on phenol degradation is presented in Fig. 5. Phenol degradation efficiency decreased with increasing phenol concentration. The complete phenol removal could be achieved at phenol concentration of $25 \mathrm{mg} / \mathrm{L}$ in $60 \mathrm{~min}$ while at phenol concentration of 50,75 and $100 \mathrm{mg} / \mathrm{L}$, removal efficiency obtained in 120 min were 98, 91 and 75\%, respectively. Due to the same concentration of $\mathrm{Mn}_{2} \mathrm{O}_{3}$ and PMS, SR concentrations produced in solution will be the same. Thus, high amount of phenol in solution will require more time to achieve the same removal rate, thus lowering phenol degradation efficiency.

[Insert Fig. 5]

Phenol removal efficiency is also affected by $\mathrm{Mn}_{2} \mathrm{O}_{3}$ loading in the system as shown in Fig. 6. A complete removal of phenol could be reached within 60 min at $0.4 \mathrm{~g} / \mathrm{L} \mathrm{Mn}_{2} \mathrm{O}_{3}$ loading. While 97.7, 93.3, and $68 \%$ removals could be reached in $120 \mathrm{~min}$ at $\mathrm{Mn}_{2} \mathrm{O}_{3}$ loading of $0.30,0.20$, and $0.10 \mathrm{~g} / \mathrm{L}$, respectively. For phenol degradation, increased catalyst loading would enhance the rate of activation of PMS to generate the active SRs, resulting in an increase in the rate of phenol removal.

[Insert Fig. 6]

Fig. 7 illustrates the effect of PMS concentration on phenol oxidation. As expected, phenol degradation rate was increased when PMS concentration was increased from 0.8 to $2 \mathrm{~g} / \mathrm{L}$. However, further increase in PMS concentration would decrease phenol degradation efficiency, suggesting the optimal loading at $2 \mathrm{~g} / \mathrm{L}$. Some investigations have shown the similar observation in Co/PMS systems $[32,34]$. It has been believed that extra $\mathrm{HSO}_{5}{ }^{-}$in solution can react with $\mathrm{SO}_{4}^{-\bullet}$ generating $\mathrm{SO}_{5}^{-\bullet}$, which has lower reaction rate than $\mathrm{SO}_{4}^{-\bullet}$, resulting in decreased phenol degradation.

[Insert Fig. 7] 
In addition, the temperature is also a key factor influencing catalyst activity on phenol degradation. Fig. 8 shows the effect of temperature on phenol degradation. Higher phenol removal was obtained at increased temperature. For instance, at temperature of $25{ }^{\circ} \mathrm{C}$, the complete removal of phenol was achieved in 60 min while at 35 and $45^{\circ} \mathrm{C}$, complete removal of phenol could be achieved in 40 and $30 \mathrm{~min}$, respectively.

[Insert Fig. 8]

In order to estimate the kinetic rates at varying temperatures, a general pseudo first order kinetics for phenol degradation was employed, as shown in equation below.

$$
\mathrm{C}=\mathrm{C}_{0} \exp \left(-\mathrm{k}_{\mathrm{obs}} \times \mathrm{t}\right)
$$

Where $\mathrm{k}_{\mathrm{obs}}\left(\mathrm{min}^{-1}\right)$ is the apparent first order rate constant of phenol removal, $\mathrm{C}$ is the concentration of phenol (ppm) at various time $(\mathrm{t}, \mathrm{min}) . \mathrm{C}_{\mathrm{o}}$ is the initial phenol concentration (ppm). Data fitting (Fig. 8) showed that phenol degradation could be described by the first order kinetics. Kinetic constants are presented in Table 2. As can be seen that kinetic rate of reaction would be increased with increasing temperature. Furthermore, the Arrhenius plot of rate constants with temperature for $\mathrm{Mn}_{2} \mathrm{O}_{3}$ presented a good linear correlation (Fig.9) and the activation energy for $\mathrm{Mn}_{2} \mathrm{O}_{3}$ was derived as $11.4 \mathrm{~kJ} / \mathrm{mol}$. Yao et al. [35] very recently reported a $\mathrm{Mn}_{3} \mathrm{O}_{4} / \mathrm{Graphene}$ system in activation of PMS for Orange II degradation and found the activation energy at $49.5 \mathrm{~kJ} / \mathrm{mol}$. Our previous investigations on $\mathrm{Co}_{3} \mathrm{O}_{4}$-based systems for phenol degradation showed that activation energies of supported $\mathrm{Co}_{3} \mathrm{O}_{4}$ catalysts are in the range of $47-70 \mathrm{~kJ} / \mathrm{mol}[21,31,36,37]$. Therefore, $\mathrm{Mn}_{2} \mathrm{O}_{3}$ presents much lower activation energy than other catalysts and would be a promising material.

Table 2. Kinetic constants of phenol degradation at different temperatures on $\alpha-\mathrm{Mn}_{2} \mathrm{O}_{3}$ catalyst.

\begin{tabular}{cccc}
\hline Catalyst & Temperature, ${ }^{\circ} \mathrm{C}$ & $\mathrm{k}\left(\mathrm{min}^{-1}\right)$ & $\mathrm{R}^{2}$ \\
\hline $\mathrm{Mn}_{2} \mathrm{O}_{3}$ & 25 & 0.087 & 0.97 \\
& 35 & 0.122 & 0.96 \\
& 45 & 0.154 & 0.99 \\
\hline
\end{tabular}

[Insert Fig. 9]

\subsection{Reactivity of spent $\alpha-\mathrm{Mn}_{2} \mathrm{O}_{3}$ catalyst and reusability}

Fig. 10 shows the catalytic activity of recycled $\alpha-\mathrm{Mn}_{2} \mathrm{O}_{3}$ for phenol degradation. As can be seen, the catalytic activity was significantly reduced in the second use if the catalyst was recovered by simple water washing, suggesting a deactivation of the catalyst. In the second use, phenol degradation was 
$27 \%$ at 120 min compared with $100 \%$ in the first use. However, after heat treatment at $500{ }^{\circ} \mathrm{C}$ for 1 hour, the activity of $\alpha-\mathrm{Mn}_{2} \mathrm{O}_{3}$ was fully recovered and complete degradation of phenol can be achieved at $120 \mathrm{~min}$ as the same as the first use.

Deactivation of $\alpha-\mathrm{Mn}_{2} \mathrm{O}_{3}$ could be attributed to intermediate deposition on the surface and chemical phase change[38]. XRD analysis showed that no phase change occurred after reaction. This suggests that the intermediate deposits on the catalyst surface plays important role for catalyst deactivation and they can be removed by heat treatment.

\section{Conclusions}

Different oxidation states of manganese oxide were synthesized and tested for catalytic oxidation of phenolic contaminants with PMS. Among them, $\mathrm{Mn}_{2} \mathrm{O}_{3}$ is the most effective catalyst for generating SRs to degrade phenol. The catalytic activity followed the trend of $\mathrm{Mn}_{2} \mathrm{O}_{3}>\mathrm{MnO}>\mathrm{Mn}_{3} \mathrm{O}_{4}>$ $\mathrm{MnO}_{2}$, which is related to redox potential. Several reaction factors influenced the removal efficiency of phenol such as PMS concentration, phenol concentration, catalyst loading and temperature. Kinetic studies showed that the phenol degradation followed first order reaction and activation energy of $\mathrm{Mn}_{2} \mathrm{O}_{3}$ were obtained to be $11.4 \mathrm{~kJ} / \mathrm{mol}$. Although deactivation occurred on $\mathrm{Mn}_{2} \mathrm{O}_{3}$, the activity could be fully recovered by high temperature calcination.

\section{Reference}

[1] S.G. Christoskova, M. Stoyanova, M. Georgieva, Applied Catalysis A: General 208 (2001) 243-249.

[2] A. Fortuny, C. Bengoa, J. Font, A. Fabregat, Journal of Hazardous Materials 64 (1999) 181193.

[3] V. Dohnal, D. Fenclova, Journal of Chemical \& Engineering Data 40 (1995) 478-483.

[4] A. Marco, S. Esplugas, G. Saum, Water Science and Technology 35 (1997) 321-327.

[5] R. Andreozzi, V. Caprio, A. Insola, R. Marotta, Catalysis Today 53 (1999) 51-59.

[6] C.-P. Huang, Y.-H. Huang, Applied Catalysis A: General 357 (2009) 135-141.

[7] G. Calleja, J.A. Melero, F. Martínez, R. Molina, Water Research 39 (2005) 1741-1750.

[8] K. Fajerwerg, H. Debellefontaine, Applied Catalysis B: Environmental 10 (1996) L229L235.

[9] S. Liang, F. Teng, G. Bulgan, R. Zong, Y. Zhu, The Journal of Physical Chemistry C 112 (2008) 5307-5315.

[10] M.I. Zaki, M.A. Hasan, L. Pasupulety, Applied Catalysis A: General 198 (2000) 247-259. 
[11] M. Baldi, E. Finocchio, F. Milella, G. Busca, Applied Catalysis B: Environmental 16 (1998) 43-51.

[12] M. Fang, X. Tan, M. Liu, S. Kang, X. Hu, L. Zhang, CrystEngComm 13 (2011) 4915-4920.

[13] M. Yang, D. Li, T. Zhao, J. Ma, Journal of Dispersion Science and Technology 31 (2010) 563-566.

[14] F. Zhou, X. Zhao, C. Yuan, H. Xu, Journal of Materials Science 42 (2007) 9978-9982.

[15] R. Wu, J. Qu, Y. Chen, Water Research 39 (2005) 630-638.

[16] S.C. Kim, W.G. Shim, Applied Catalysis B: Environmental 98 (2010) 180-185.

[17] K. Ramesh, L. Chen, F. Chen, Y. Liu, Z. Wang, Y.-F. Han, Catalysis Today 131 (2008) 477-482.

[18] V. Santos, M. Pereira, J. Órfão, J. Figueiredo, Topics in Catalysis 52 (2009) 470-481.

[19] G.P. Anipsitakis, D.D. Dionysiou, Environmental Science \& Technology 37 (2003) 47904797.

[20] G.P. Anipsitakis, D.D. Dionysiou, Environmental Science \& Technology 38 (2004) 37053712 .

[21] E. Saputra, S. Muhammad, H. Sun, H.M. Ang, M.O. Tadé, S. Wang, Catalysis Today 190 (2012) 68-72.

[22] S. Muhammad, P.R. Shukla, M.O. Tadé, S. Wang, Journal of Hazardous Materials 215-216 (2012) 183-190.

[23] S. Muhammad, E. Saputra, H. Sun, J.d.C. Izidoro, D.A. Fungaro, H.M. Ang, M.O. Tade, S. Wang, RSC Advances 2 (2012) 5645-5650.

[24] J.A. Zazo, J.A. Casas, A.F. Mohedano, M.A. Gilarranz, J.J. Rodríguez, Environmental Science \& Technology 39 (2005) 9295-9302.

[25] R. Watts, J. Sarasa, F. Loge, A. Teel, Journal of Environmental Engineering 131 (2005) 158-164.

[26] E. Saputra, S. Muhammad, H. Sun, A. Patel, P. Shukla, Z.H. Zhu, S. Wang, Catalysis Communications 26 (2012) 144-148.

[27] S. Lei, K. Tang, Z. Fang, Q. Liu, H. Zheng, Materials Letters 60 (2006) 53-56.

[28] H.T. Zhu, J. Luo, H.X. Yang, J.K. Liang, G.H. Rao, J.B. Li, Z.M. Du, The Journal of Physical Chemistry C 112 (2008) 17089-17094.

[29] M.J. Aragón, B. León, C. Pérez Vicente, J.L. Tirado, Journal of Power Sources 196 (2011) 2863-2866.

[30] H.-Y. Li, J.-H. Qu, X. Zhao, H.-J. Liu, Journal of Environmental Science and Health, Part B 39 (2004) 791-803. 
[31] P. Shukla, H. Sun, S. Wang, H.M. Ang, M.O. Tadé, Separation and Purification Technology 77 (2011) 230-236.

[32] P. Shukla, H. Sun, S. Wang, H.M. Ang, M.O. Tadé, Catalysis Today 175 (2011) 380-385.

[33] Q. Yang, H. Choi, S.R. Al-Abed, D.D. Dionysiou, Applied Catalysis B-Environmental 88 (2009) 462-469.

[34] P. Shukla, I. Fatimah, S. Wang, H.M. Ang, M.O. Tadé, Catalysis Today 157 (2010) 410414.

[35] Y. Yao, C. Xu, S. Yu, D. Zhang, S. Wang, Industrial \& Engineering Chemistry Research (2013).

[36] P. Shukla, S. Wang, K. Singh, H.M. Ang, M.O. Tadé, Applied Catalysis B: Environmental 99 (2010) 163-169.

[37] P.R. Shukla, S. Wang, H. Sun, H.M. Ang, M. Tadé, Applied Catalysis B: Environmental 100 (2010) 529-534.

[38] H. Sun, H. Liang, G. Zhou, S. Wang, Journal of Colloid and Interface Science 394 (2013) 394-400. 


\section{List of Figures}

Fig. 1 TGA profiles of (A) $\mathrm{MnO}_{2}$, (B) $\mathrm{MnCO}_{3}$ in air and argon, respectively, at a heating rate of 10 ${ }^{\circ} \mathrm{C} / \mathrm{min}$.

Fig. 2 XRD patterns of manganese oxide catalysts. (A) $\gamma-\mathrm{MnO}_{2}$, (B) $\mathrm{MnO}$, (C) $\gamma-\mathrm{Mn}_{3} \mathrm{O}_{4}$, and (D) $\alpha$ $\mathrm{Mn}_{2} \mathrm{O}_{3}$

Fig. $3 \mathrm{~N}_{2}$ adsorption isotherm and pore size distributions of manganese oxide catalysts. (A) $\mathrm{N}_{2}$ isotherm and (B) pore size distributions.

Fig. 4 Phenol removal efficiency in catalytic oxidation using a series of manganese oxides. Reaction condition: $\left[\right.$ Phenol] $=25 \mathrm{ppm}$, catalyst $=0.4 \mathrm{~g} / \mathrm{L}, \mathrm{PMS}=2 \mathrm{~g} / \mathrm{L}$, and $\mathrm{T}=25^{\circ} \mathrm{C}$.

Fig. 5 Effect of phenol concentration on phenol removal. Reaction condition: catalyst $\left(\mathrm{Mn}_{2} \mathrm{O}_{3}\right)=$ $0.4 \mathrm{~g} / \mathrm{L}, \mathrm{PMS}=2 \mathrm{~g} / \mathrm{L}$, and $\mathrm{T}=25^{\circ} \mathrm{C}$.

Fig. 6 Effect of catalyst loading $\left(\mathrm{Mn}_{2} \mathrm{O}_{3}\right)$ on phenol removal. Reaction condition: [Phenol] $=25$ ppm, PMS $=2 \mathrm{~g} / \mathrm{L}$, and $\mathrm{T}=25^{\circ} \mathrm{C}$.

Fig. 7 Effect of oxone concentration on phenol removal. Reaction condition: [Phenol] $=25 \mathrm{ppm}$, catalyst $\left(\mathrm{Mn}_{2} \mathrm{O}_{3}\right)=0.4 \mathrm{~g} / \mathrm{L}$, and $\mathrm{T}=25^{\circ} \mathrm{C}$.

Fig. 8 Effect of temperature on phenol removal. Reaction condition: [Phenol] $=25$ ppm, catalyst $\left(\mathrm{Mn}_{2} \mathrm{O}_{3}\right)=0.4 \mathrm{~g} / \mathrm{L}$, and PMS $=2 \mathrm{~g} / \mathrm{L}$.

Fig. 9 Arrhenius plot of phenol degradation on $\mathrm{Mn}_{2} \mathrm{O}_{3}$ catalyst.

Fig. 10 Phenol degradation efficiency of recycled $\mathrm{Mn}_{2} \mathrm{O}_{3}$ catalysts. Reaction condition: [Phenol] = $25 \mathrm{ppm}$, catalyst $=0.4 \mathrm{~g} / \mathrm{L}, \mathrm{PMS}=2 \mathrm{~g} / \mathrm{L}$, and $\mathrm{T}=25{ }^{\circ} \mathrm{C}$. 


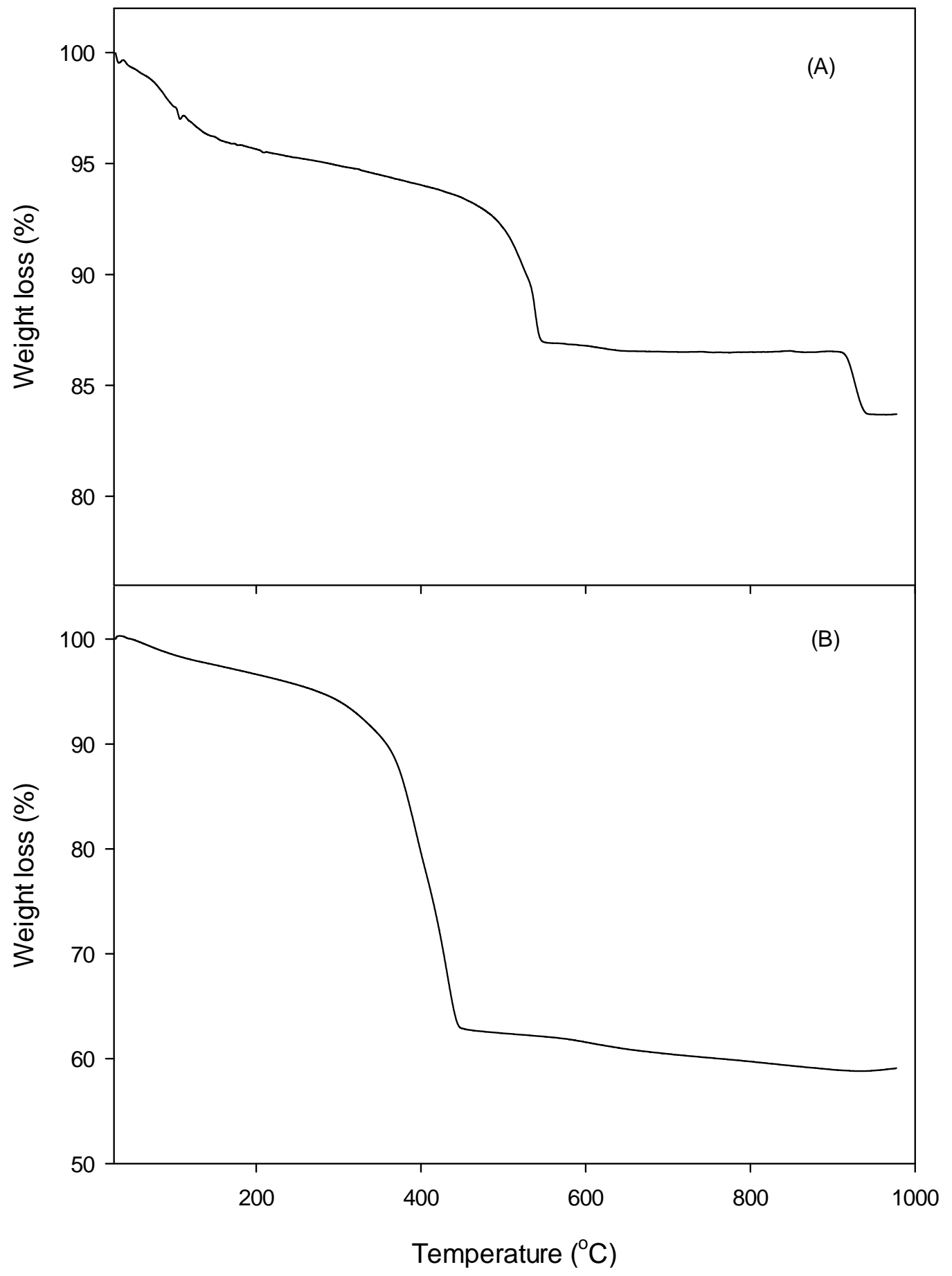

Fig. 1 TGA profiles of (A) $\mathrm{MnO}_{2}$, (B) $\mathrm{MnCO}_{3}$ in air and argon, respectively, at a heating rate of 10 ${ }^{\circ} \mathrm{C} \min ^{-1}$. 

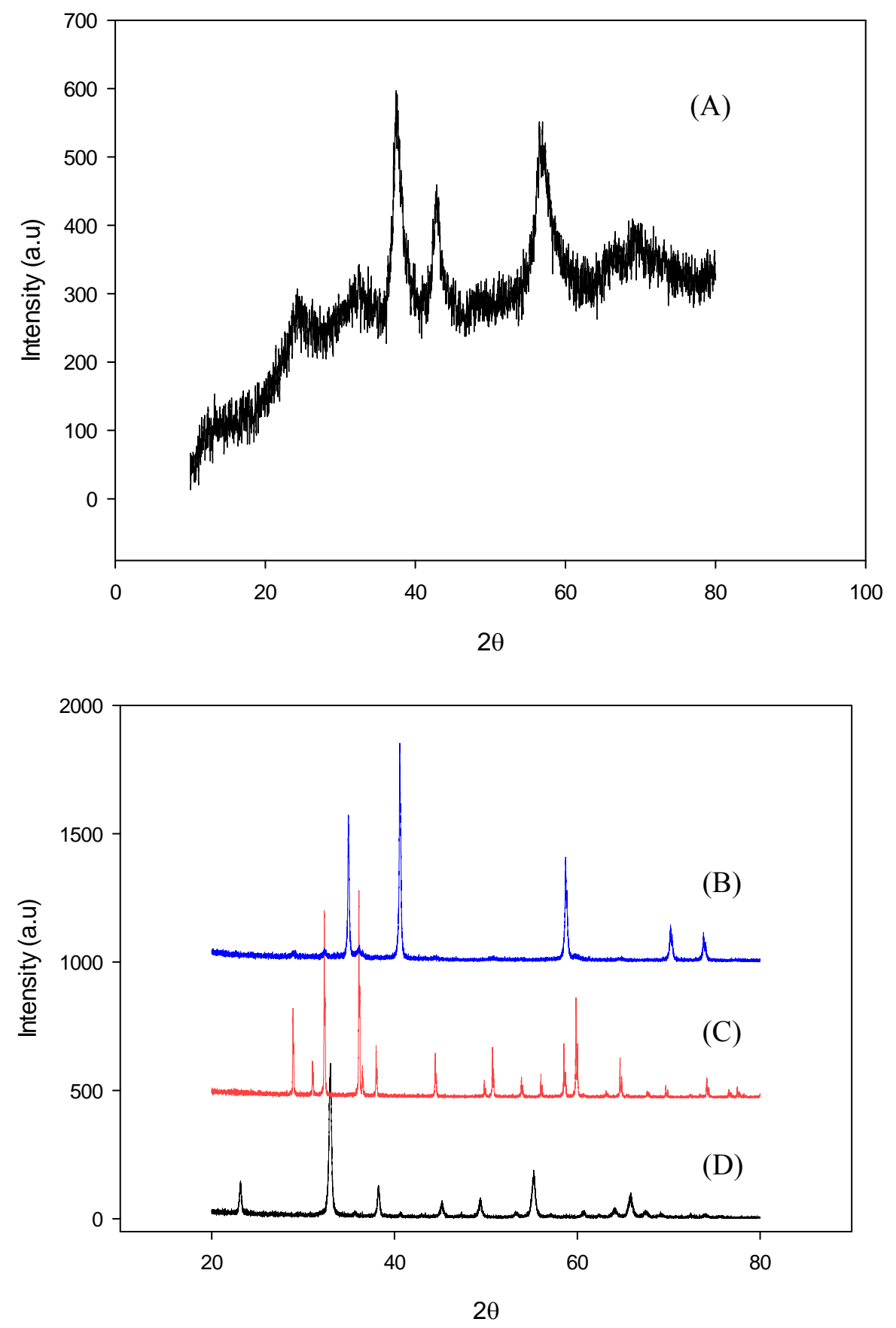

Fig. 2 XRD patterns of manganese oxide catalysts. (A) $\gamma-\mathrm{MnO}_{2}$, (B) $\mathrm{MnO}$, (C) $\gamma-\mathrm{Mn}_{3} \mathrm{O}_{4}$, and (D) $\alpha-$ $\mathrm{Mn}_{2} \mathrm{O}_{3}$ 

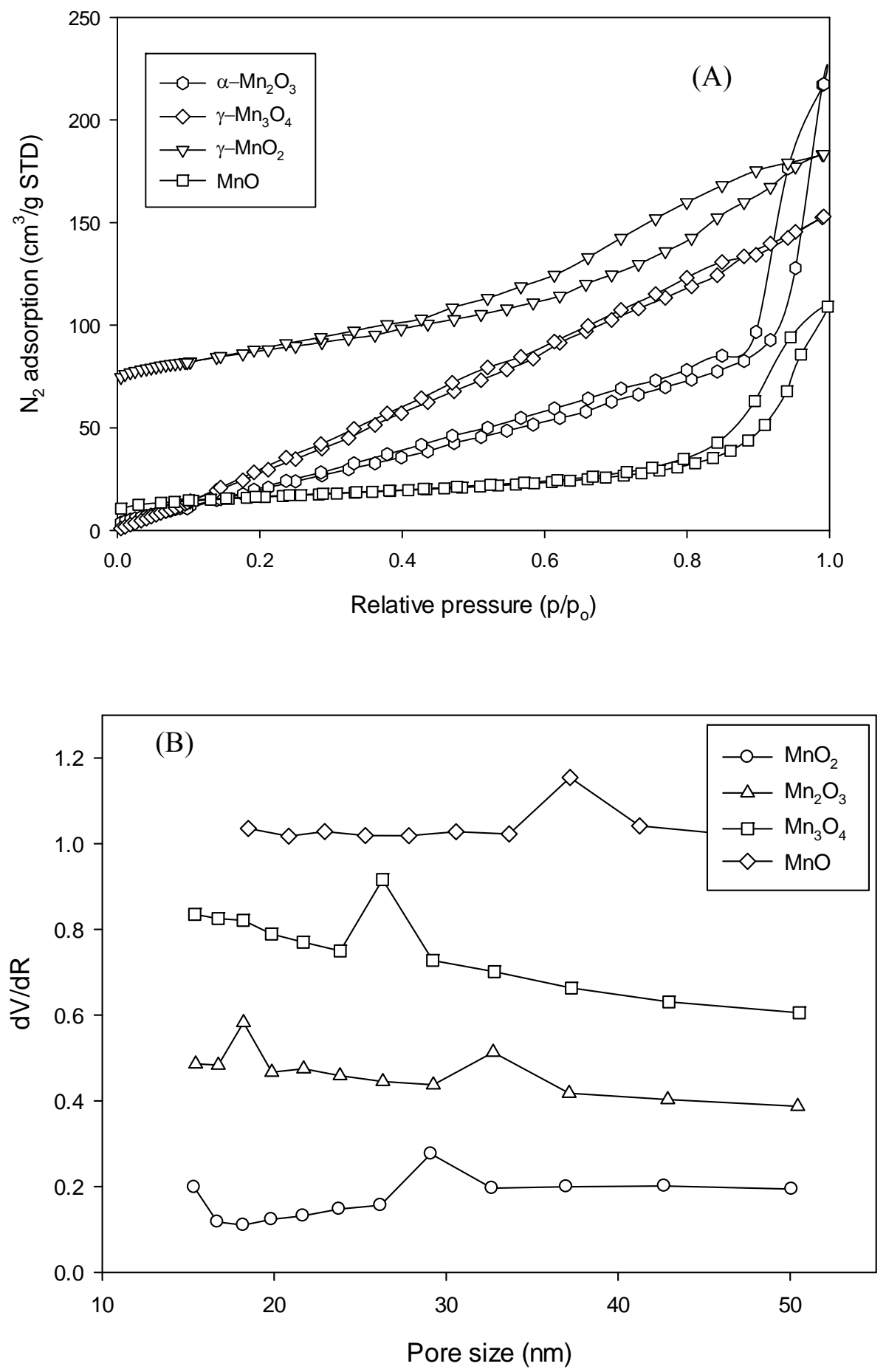

Fig. $3 \mathrm{~N}_{2}$ adsorption isotherm and pore size distributions of manganese oxide catalysts. (A) $\mathrm{N}_{2}$ isotherm and $(\mathrm{B})$ pore size distributions. 


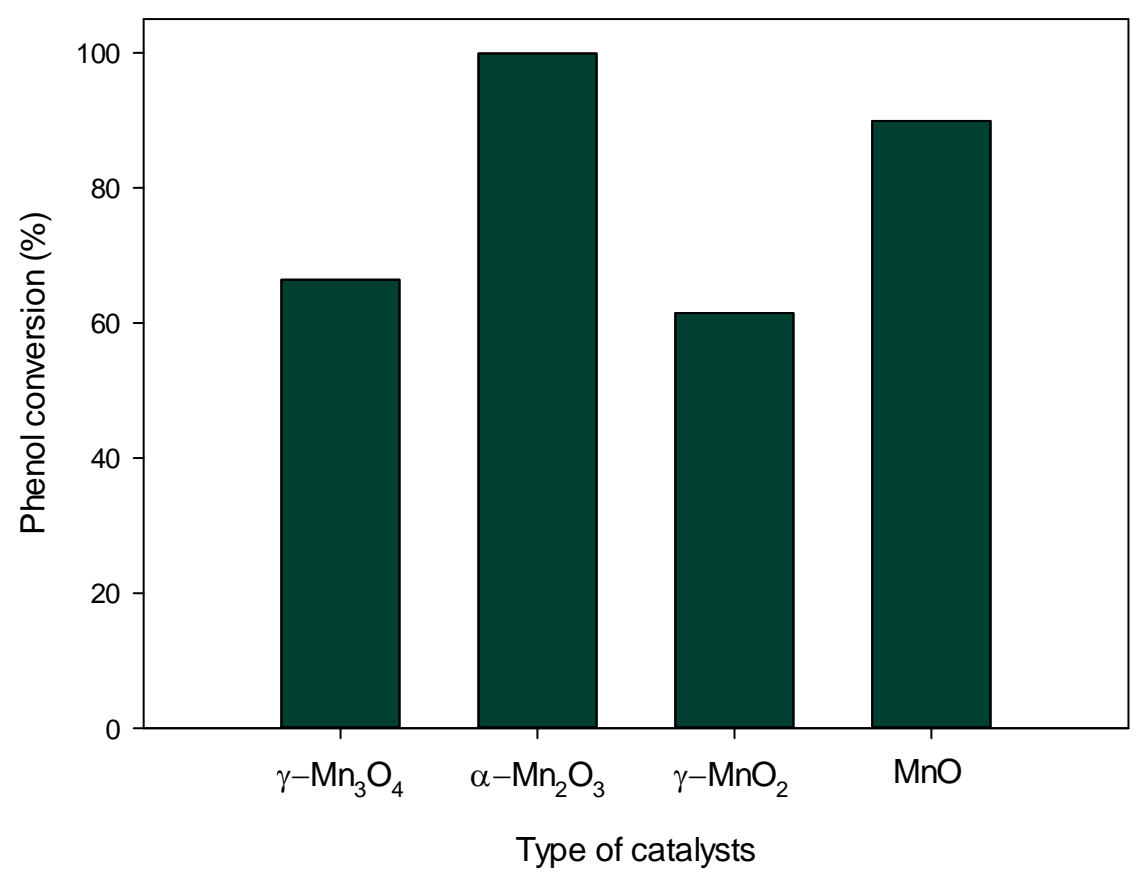

Fig. 4 Phenol removal efficiency in catalytic oxidation using a series of manganese oxides. Reaction condition: $[$ Phenol $]=25 \mathrm{ppm}$, catalyst $=0.4 \mathrm{~g} / \mathrm{L}, \mathrm{PMS}=2 \mathrm{~g} / \mathrm{L}$, and $\mathrm{T}=25^{\circ} \mathrm{C}$. 


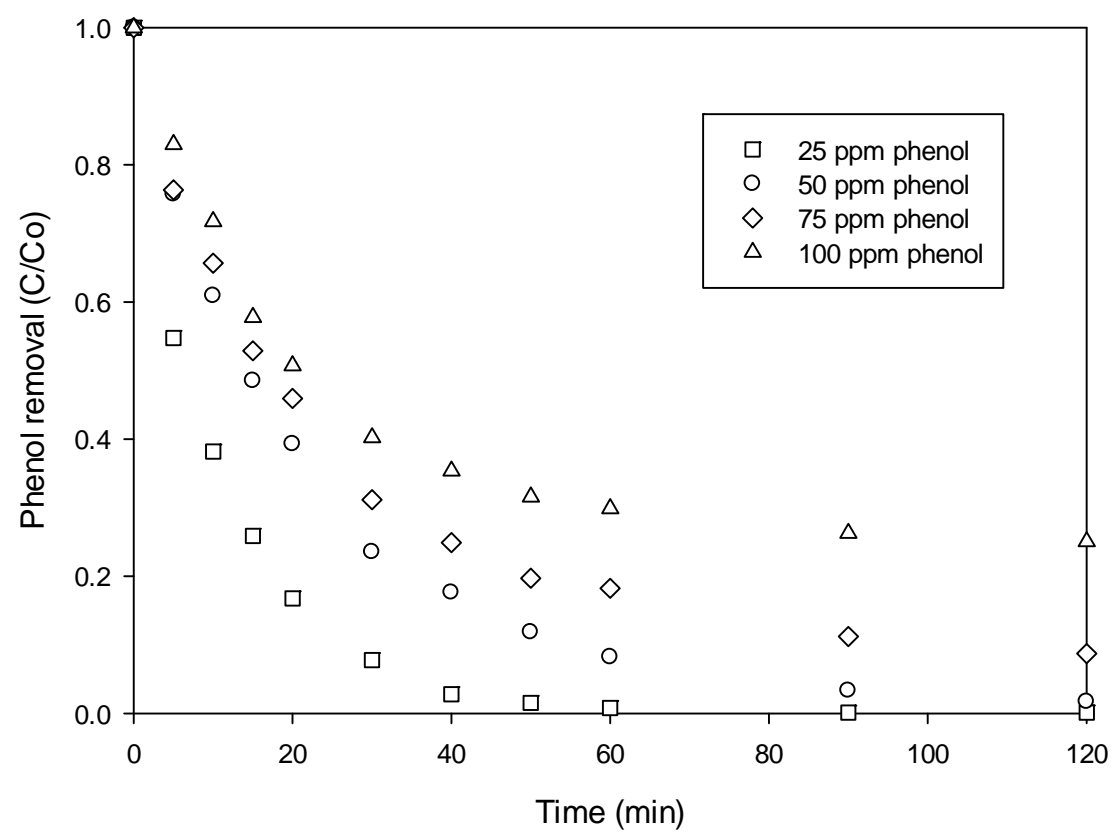

Fig. 5 Effect of phenol concentration on phenol removal. Reaction condition: catalyst $\left(\mathrm{Mn}_{2} \mathrm{O}_{3}\right)=$ $0.4 \mathrm{~g} / \mathrm{L}, \mathrm{PMS}=2 \mathrm{~g} / \mathrm{L}$, and $\mathrm{T}=25{ }^{\circ} \mathrm{C}$. 


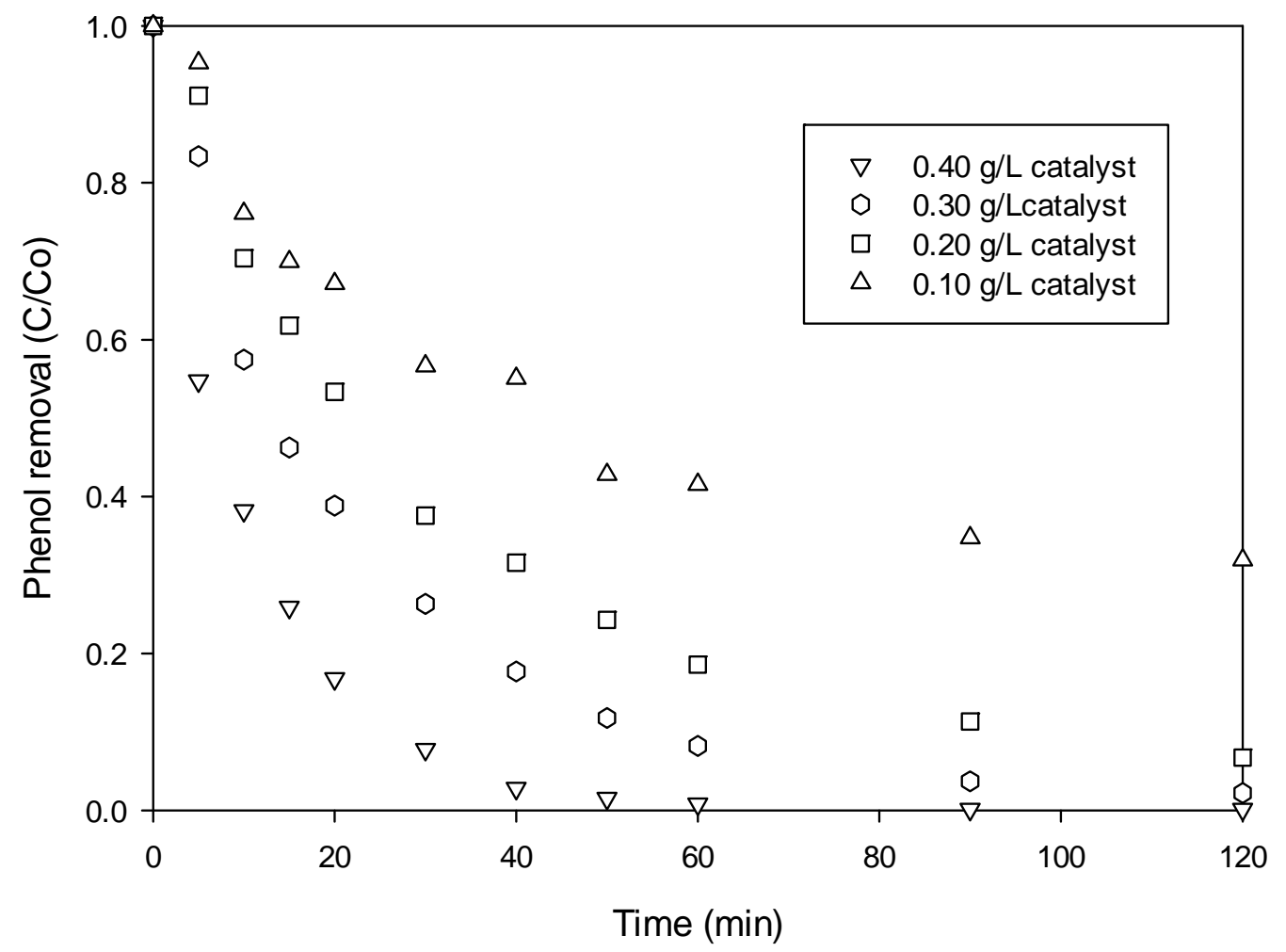

Fig. 6 Effect of catalyst loading $\left(\mathrm{Mn}_{2} \mathrm{O}_{3}\right)$ on phenol removal. Reaction condition: [Phenol] $=25$ ppm, PMS $=2 \mathrm{~g} / \mathrm{L}$, and $\mathrm{T}=25^{\circ} \mathrm{C}$. 


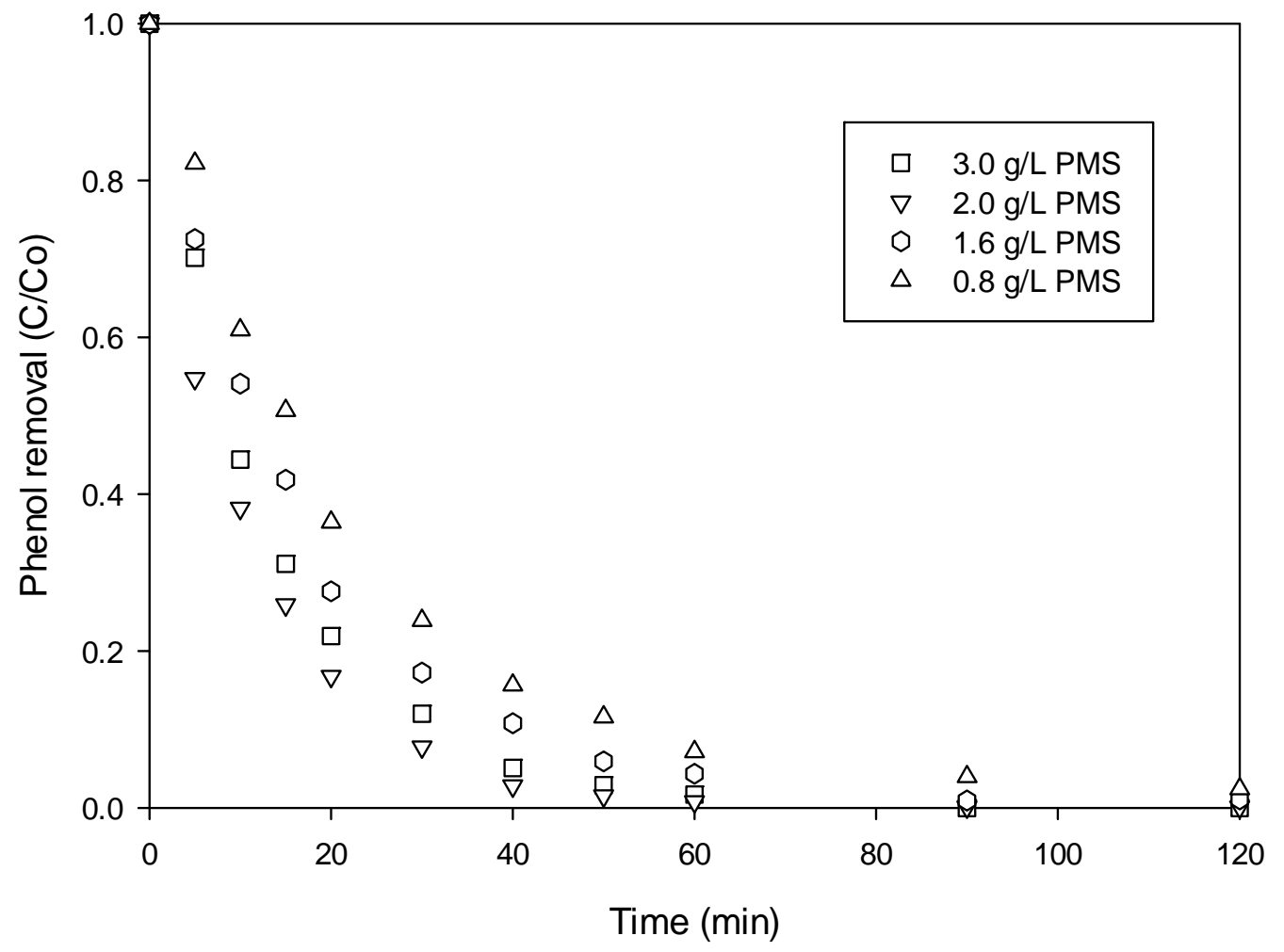

Fig. 7 Effect of oxone concentration on phenol removal. Reaction condition: [Phenol] $=25 \mathrm{ppm}$, catalyst $\left(\mathrm{Mn}_{2} \mathrm{O}_{3}\right)=0.4 \mathrm{~g} / \mathrm{L}$, and $\mathrm{T}=25^{\circ} \mathrm{C}$. 


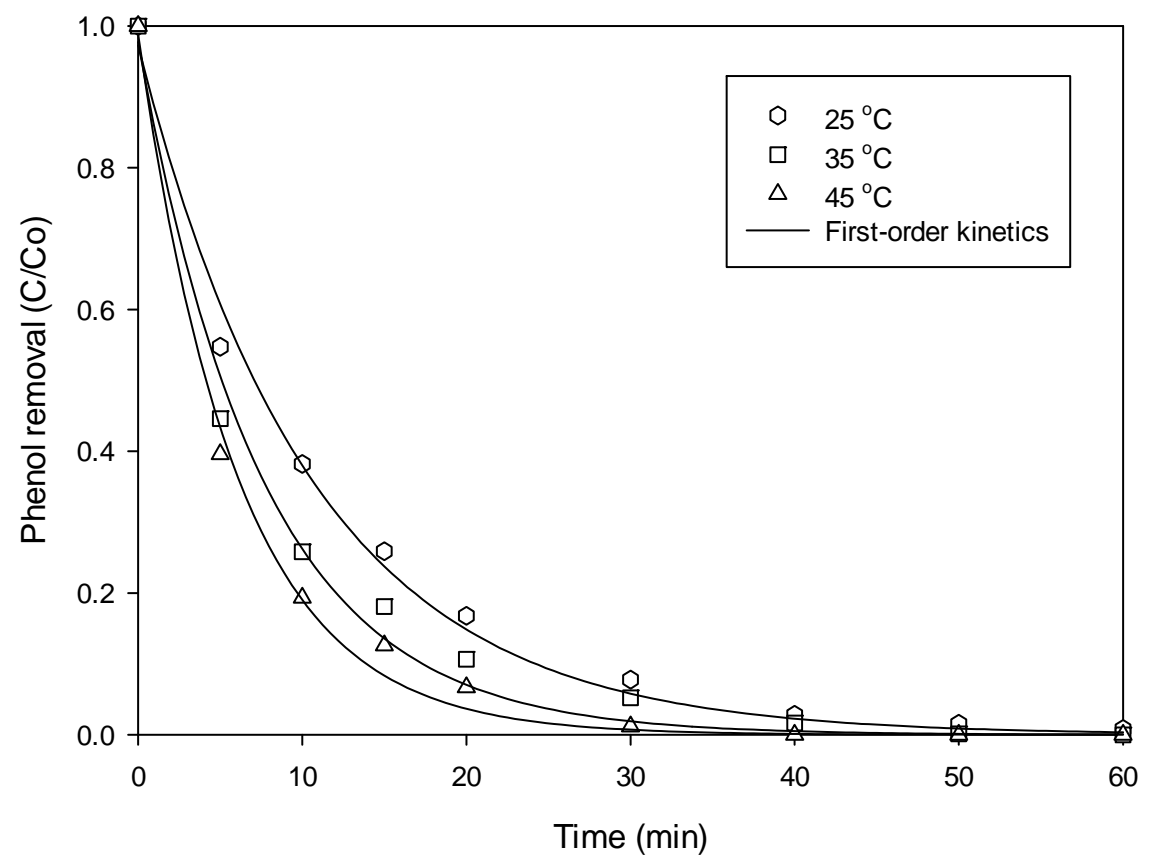

Fig. 8 Effect of temperature on phenol removal. Reaction condition: [Phenol] $=25$ ppm, catalyst $\left(\mathrm{Mn}_{2} \mathrm{O}_{3}\right)=0.4 \mathrm{~g} / \mathrm{L}$, and PMS $=2 \mathrm{~g} / \mathrm{L}$. 


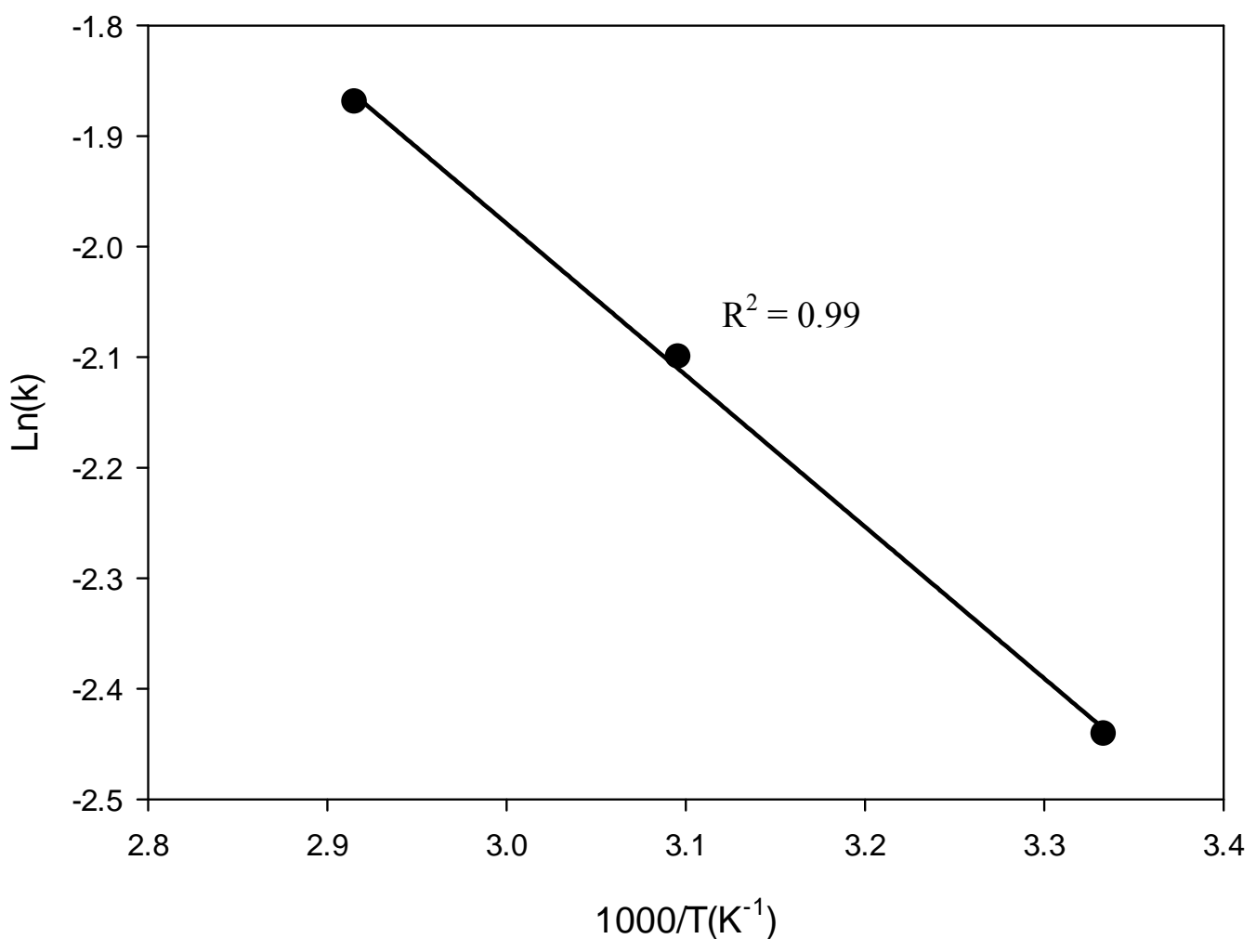

Fig. 9 Arrhenius plot of phenol degradation on $\mathrm{Mn}_{2} \mathrm{O}_{3}$ catalyst. 


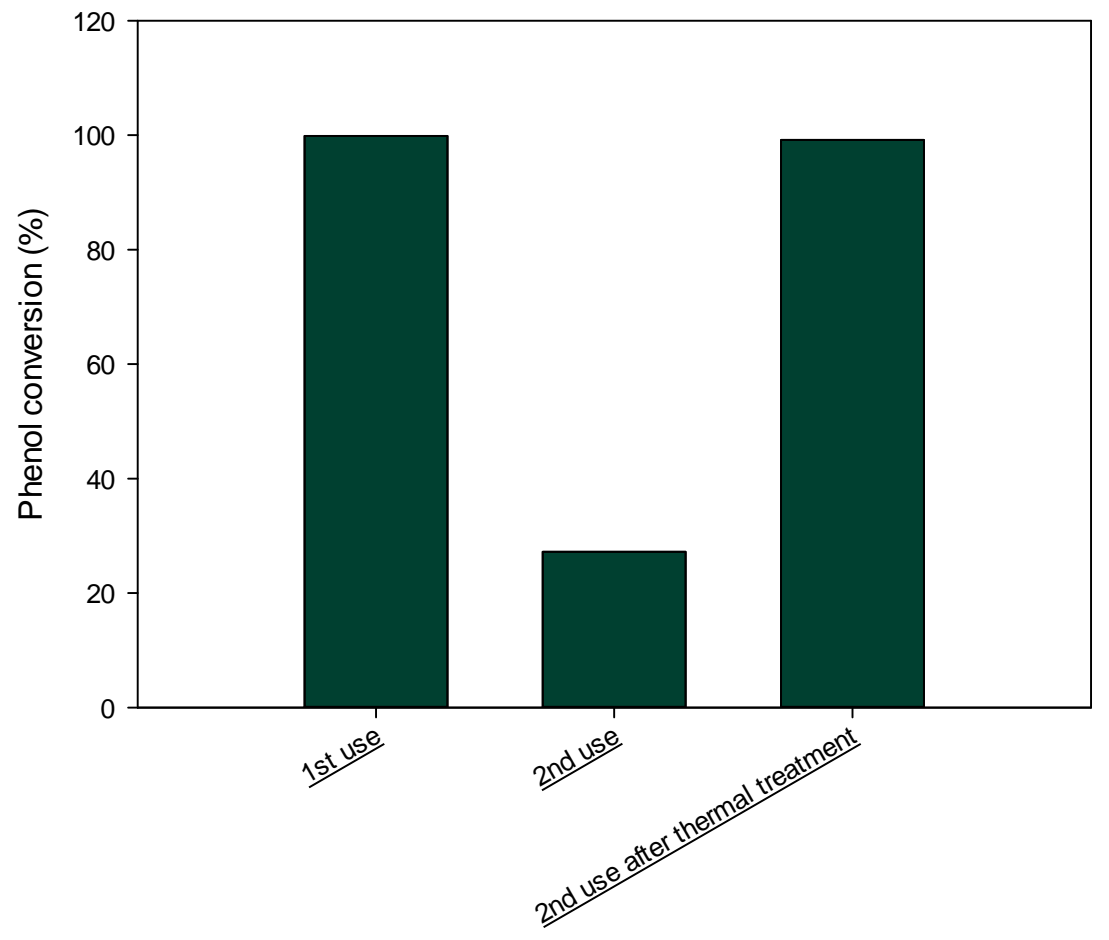

Fig. 10 Phenol degradation efficiency of recycled $\mathrm{Mn}_{2} \mathrm{O}_{3}$ catalysts. Reaction condition: [Phenol] = $25 \mathrm{ppm}$, catalyst $=0.4 \mathrm{~g} / \mathrm{L}, \mathrm{PMS}=2 \mathrm{~g} / \mathrm{L}$, and $\mathrm{T}=25^{\circ} \mathrm{C}$. 